\title{
Segmentation, Targeting and Positioning of Indian Furniture Industry
}

\author{
Neeraj Kumari (Corresponding author) \\ Department of Applied Sciences, Faculty of Engineering and Technology \\ Manav Rachna International Institute of Research and Studies \\ Aravali Hills, Sector-43, Faridabad - 121001, Haryana, India \\ E-mail: neerajnarwat@gmail.com
}

Devi Singh

Department of Applied Sciences, Faculty of Engineering and Technology

Manav Rachna International Institute of Research and Studies

Aravali Hills, Sector-43, Faridabad - 121001, Haryana, India

Received: June 13, 2020

doi:10.5296/ijafr.v10i3.17500
Accepted: July 25, 2020

Published: August 7, 2020

URL: https://doi.org/10.5296/ijafr.v10i3.17500

\begin{abstract}
Objectives:

- To study the segmentation, targeting and positioning of furniture industry.

- To make and study ANSOFF grid for the key player in the plastic furniture industry.

- To recommend advertising strategies for the plastic furniture industry.
\end{abstract}

Research Design: Information has been gathered from both primary and secondary sources. Primary data was collected through a structured questionnaire. Secondary data sources include websites, journals, and research papers.

Sample Design: Convenience Sampling was carried out for the study. The sample consisted of customers who had bought products from the furniture industry. The sample size is 120 .

Novelty of the study/ Contribution to the literature: It could bear some significance with lead an examination on more territories of promoting and including the distinctive focused on 
clients which would give more exhaustive understanding and outline of the point.

Findings: People with low resources believers, strivers, makers, survivors are most likely to buy the plastic furniture as of now when the product is in growth stage of its life cycle. Nilkamal plastics have been successful in positioning its products well in the market. It became popular especially in South India, where consumers prefer simple living and hence had a demand for plastic furniture too.

Recommendations: Nilkamal can promote its brand based on the driving factors: lightweight, weatherproof, termite-proof, and economical.

Implications: The findings of the study have implications for branding, positioning decisions, brand equity measurement and marketing communications. The essential ramification of an advancing framework is the presentation toward tending to customer needs those results in extended purchaser dependability. A publicizing methodology has basic ramifications for things such as design and progression.

Keywords: ANSOFF, Plastic, Advertising, Wood, Marketing

\section{Introduction}

\subsection{Overview of the Global Furniture Market}

Research examination on the worldwide furniture market recognizes that the advancement of new plans in the market because of the developing interest among the shoppers as one of the main considerations filling market development. The merchants in the market are thinking of new stoops utilizing recyclable materials. Such advancements will add to the market's development. Moreover, with the developing tourism the market is additionally seeing the presentation of furniture with local and social impacts.

The rising interest for multi-useful furniture which gives different highlights, for example, the accessibility of storerooms is one of the significant patterns that will pick up footing in this market amid the following four years. The rising use of cell phones, tablets, and different devices has expanded the interest for pockets for capacity or docks for charging these devices. The sellers in the market are giving diverse items as indicated by the taste and inclinations of the shoppers, which will thusly enhance advertise development.

\subsection{Nilkamal Limited}

Established by original business visionaries, the corporate administration of NILKAMAL LIMITED is youthful and ready to lead the Organization to more noteworthy statures. Keeping up administration in its market fragments through center qualities and diligent work is an essential fundamental driving the Organization.

Nilkamal Plastics LTD is world's No. I company in Moulded Furniture. The total consumption of raw material is 55,000 metric tons per annum. In terms of chairs Nilkamal sells close to one crore chairs per annum. Nilkamal came into existence in the year 1950 with a modest beginning of manufacturing plastics buttons. Nilkamal has two divisions: 
- Material Handling Crates

- Moulded Furniture

The moulded Furniture division was started in the year 1990. Today Nilkamal has a very strong base not only in India but also in Bangladesh and Srilanka. Nilkamal has diversified distribution channels i.e. 550 Distributors, Presence in all major Key accounts like Pepsi, Coke, Big Bazars etc, CSD and all World Bank sponsored programs. It has 17 manufacturing units in India and 1 each in Bangladesh and Srilanka. Nilkamal is the dominant player in moulded furniture industry; the market is divided into Un-organized and organized sector.

\section{Literature Review}

Flikkema et al (2019) Organizations prefer using distinctive strategies for branding which have useful implications on the design of new trademarks and the applications of the same. It found that the trademarks for creation of a brand relates to its product innovation.

Iqbal (2018) The idea of shopping from retail shopping centers is very basic in created nations. This pattern is new in creating nations all the more particularly in the sub-landmass i.e. India, Pakistan and Bangladesh. Clients lean toward retail shopping centers on little retail shops these days. This inclination demonstrates the significance of current retailing pattern. In retail shopping centers, there are the complexities on account of the nearness of numerous variables like eateries, diversion, lavish condition; propelled client benefit designs, regularly expanding deals advancement exercises and so forth. Today, the shopping isn't the perfect looking for changed family units living in the sub-continent; it has turned into a trip for them. This move in retail industry is very clear in urban territories. The general population living in rustic territories still buy from little retail shops. Shopping centers give assortment of items for families as well as for little retail businesspeople, school canteens and so on.

Pangemanan \& Walukow (2018) The outcome demonstrates that the home business is extremely focused as far as consistency, however as far as advancement, item quality, value, item expansion, plan preparing of furniture, administration and monetary scale, it is falling behind. The home business ought to have the capacity to create advertising organizing, enhance plan and item quality, advancement and cost control, item expansion and these must be finished by escalated preparing in overseeing business and venture.

Masuda (2017) Among little and medium size organizations in creating nations, developments are expected to enhance productivity of the business and to get by in worldwide rivalry. Not just the globalization and rivalry are the difficulties, yet in addition new legality verification prerequisites set by EU and governments places organizations in another circumstance.

Bhatnagar (2017) Retailing is one of the greatest zones in the overall economy and is encountering a formative stage in India. Retail is at introducing a flourishing territory of the Indian economy. Retail is India's greatest industry, speaking to in excess of 10 percent of the country's Gross household item and around eight percent of work. Retail in India is at the intersection. 


\section{$\triangle$ Macrothink}

International Journal of Accounting and Financial Reporting

ISSN 2162-3082

2020, Vol. 10, No. 3

Narain (2017) investigates the obstructions to MC execution in small-and-medium enterprises (SMEs) engaged with furniture fabricating business and proposes panacea for these hindrances. The examination advocates the utilization of electronic item configuration alongside the improvement of system among the SMEs.

Petersen (2017) Teuer Furniture is a select, sensibly estimated chain of upscale home furnishing showrooms in the US. The firm survived the financial subsidence and before the complete of 2012, it has recovered its cash related adjust. Since the firm is more secure fiscally, a segment of its whole deal examiners have asked for to cash out their endeavors.

Schlegelmilch (2016) Leaders need to see how they can benefit from the open doors patterns may offer and limit the dangers they speak to. Consequently, the examination returns to the possibility of an adjusted way to deal with worldwide promoting methodology. It delineates how organizations need to locate the correct blend between the misuse of existing items and administrations versus the investigation of developing patterns; the developmental and progressive change in change forms; and the worldwide institutionalization and nearby adjustment to take best preferred standpoint of rising patterns.

Wang et al (2016) Building block type modular furniture has been perceived by individuals as a method for current way of life and utilization design. The plan portfolio was incorporated the components of antiquated hand enclose and conventional engineering Anhui region. By examining from the point of view of pragmatic outline, utilitarian blend and auxiliary network, the examination advances the possibility of the prevalence, distinctness, and amusement of the measured furniture in building square write. Breaking with the customary picture of conventional furniture, the position and the example of the furniture can be changed effectively as individuals wished, which will give ideal conditions to the improvement of furniture towards self-gathering.

Wensley (2016) Showcasing procedure now and then claims to give a response to a standout amongst the most troublesome inquiries in our comprehension of aggressive markets: how to perceive and accomplish a monetary preferred standpoint that perseveres. In endeavouring to do as such, advertising procedure, as with the field of technique itself, has needed to address the consistent persuasion amongst investigation and activity or, in more typical administrative terms, between methodology definition and vital execution.

Gummesson et al (2014) Shoppers are dynamically more active and the conventional provider part of controlling buyers is less suitable. The case demonstrates the assortment of manners by which organizations may receive another part in connection to clients and the market. The investigation contends that adjusting to this part change needs to occur at the most abnormal amount in the organization and is the best approach to re-evaluate showcasing system. This likewise requires advertising utilizing unusual strategies and important hypothesis to address the multifaceted nature and uncertainty of current markets. 


\section{Macrothink \\ International Journal of Accounting and Financial Reporting \\ ISSN 2162-3082 \\ 2020, Vol. 10, No. 3}

\section{Research Methodology}

\subsection{Objectives of the Study}

- To study the segmentation, targeting and positioning of furniture industry.

- To make and study ANSOFF grid for the key player in the plastic furniture industry.

- To recommend advertising strategies for the plastic furniture industry.

\subsection{Research Design}

Information has been gathered from both primary and secondary sources. Primary data was collected through a structured questionnaire filled up by the respondents. Secondary data sources include websites, journals, and research papers.

\subsection{Sample Design}

Convenience Sampling was carried out for the study. The sample consisted of customers who had bought products from the furniture industry. The sample size is 120 .

\section{Segmentation, Targeting and Positioning}

\subsection{Segmentation}

\subsubsection{Geography}

- Region: The plastic furniture industry can be segmented on the basis of region. As there is lot of changes in the preferences of the people living in different regions of India. For example, people in south and central India love to have their furniture made up only in wood. This can be one way of segmentation where the preferences of the people in different regions can be taken into consideration and marketing of plastic furniture can be gone about.

- City: Same is the case with the cities, this kind of segmentation is feasible because different cities have different population and the income levels are far different in varied cities. People with high income levels or for that matter cities with more income level will prefer wood furniture as these are considered luxury goods when compared to plastic furniture. So, demand for plastic furniture will be low in cities with high income capacity.

- Rural and semi rural areas: These are the most untapped markets in country like India, the selling appeal for products like plastic furniture would be high in these areas as the income levels are very low here.

\subsubsection{Demographics}

- Family size: If the family is a nuclear family the needs of this family from plastic furniture would limit to stools and racks at times. But in an extended family where all the members in the family cannot afford to have costly furniture in their rooms, they go for plastic furniture which is more sturdy, flexible and cheaper.

- Gender: Here, men may look for information on how the plastic furniture is flexible and sturdier than conventional furniture, and women look out for designs and patterns 
in plastic furniture.

- Income: For a lower and lower middle class people plastic furniture could be a boon, as it is affordable and nice. But when moving up on the income ladder people may want to have conventional furniture as it is thought of being a status symbol to have furniture made from teak wood in India still.

- Occupation: Students or people who change places due to career requirements may be a basis for segmenting the market. This segment of market would prefer buying Plastic furniture as it is cheap, durable, and light weight (Easy to transport).

\subsubsection{Psychographic}

Personality: Segmentation on the basis of personality would be more appropriate of all the segmentations as furniture is conventionally made from wood and the adaptation of humans from wood furniture to plastic would depend on more of the personality ones carries.

If VALS (Values and Lifestyles) segmentation frame work is considered for this classification, the following can be predicted:

- Innovators: These people may prefer the conventional wood furniture which is considered to be relatively upscale products compared to plastic furniture.

- Achievers: People of this nature may find plastic furniture as a product which will not emulate their success.

- Experiencers: These are people the marketers of plastic furniture industry could be looking for, as they are the people who become the future opinion leaders to some level. As these people try lot of things and choose the best. But a very wide variety in plastic products in several colours and designs has to be made available.

- Strivers: They favour stylish products that emulate the purchases of customers with greater material wealth. As the plastic furniture has a high chance of satisfying this need, people of this kind may find plastic furniture attractive

- Makers: Because they prefer value to luxury, they buy basic products. This can be the reason why people of this category can switch to plastic furniture.

From this it can be observed that people with low resources believers, strivers, makers, survivors are most likely to buy the plastic furniture as of now when the product is in growth stage of its life cycle. But, with this product has a high potential in future as well with the usage of the plastic furniture by experiencers, who can make the product fashionable.

At present the market leaders such as Nilkamal, Supreme etc have covered to a great extent the market for plastic products. These companies are not only involved with the individual consumers but also creating products for the industrial requirements.

\subsection{Targeting}

Undifferentiated marketing - Earlier Nilkamal used this strategy in the market. Not much choice and designs were available to consumers. Differentiated marketing strategy - Later Nilkamal shifted to this strategy. They developed several products catering to different 


\section{Mll Macrothink}

International Journal of Accounting and Financial Reporting

ISSN 2162-3082 2020, Vol. 10, No. 3

segments such as baby chairs, center tables, dining table etc and products fulfilling different requirement such as racks, crates, dustbins, industrial pellets, wash crates etc. Concentrated Marketing - The latest trend for Nilkamal. The @ Homes is the initiate taken in this direction. @ Homes is a complete home solution store with contemporary readymade wooden furniture and home accent. It typically targets the upper middle class and aspiring segment of society. It has been strategically located at several malls Nilkamal is importing the furniture which includes beds, bathroom fittings, kitchens, table set, cupboards, racks etc. Customization as per requirement of the customer is also facilitated. Thus, the company is reaching out to the consumer.

\subsection{Positioning}

Nilkamal plastics have been successful in positioning its products well in the market. Nilkamal's main points of parity are its quality and its price as compared to other varieties of furniture. For example, as compared to a wooden chair, a plastic monoblock chair of Nilkamal costs $50 \%$ less. Moreover, Nilkamal entered into the furniture industry quite early (1990), and by this time it was a well established firm, with well set business in other areas (household goods, crates). Hence, it had the funds available to advertise its product. Nilkamal was the first in the furniture sector to come up with television advertising.

Hence, with huge advantage over the other plastic furniture players in the industry, Nilkamal became a preferred brand in India. It became popular especially in south India, where consumers prefer simple living and hence had a demand for plastic furniture too. The first-mover advantage sure has paid off for Nilkamal.

\section{Ansoff Grid}

The ANSOFF grid for Nilkamal Ltd. (A key player in the plastic furniture industry) is as follows: 


\section{Macrothink \\ International Journal of Accounting and Financial Reporting

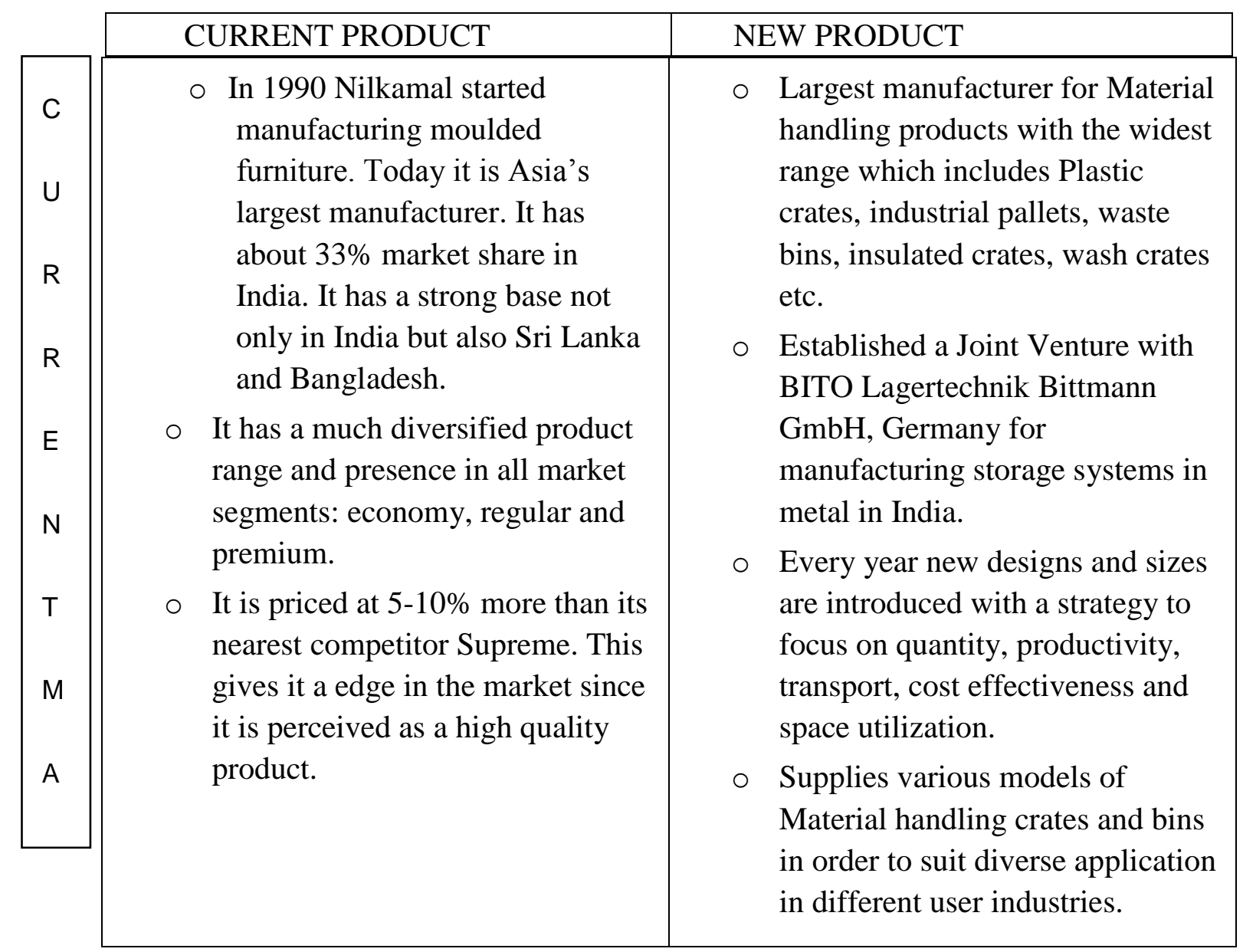




\section{\begin{tabular}{ll|ll} 
CURRENT PRODUCT & NEW PRODUCT
\end{tabular}}

o In the year 2002 Nilkamal initiated a move to reach directly to customer. It tied up with its distributor to set 300-400 sq.ft. Exclusive outlets called Home Ideas to showcase its range of plastic furniture.

- At present there are 24 such outlets but the company plans to expand.

- The main target of this initiative is to enter into the market being served by unorganized sector (About $85 \%$ of total Indian furniture industry is under unorganized sector).

- There are at present about 800 main distributors for Nilkamal furniture, which is in turn distributed to more than 15000 outlets. These contacts will help in future expansion.
- Diversified into lifestyle furniture business by @ home-complete home solution store with contemporary readymade wooden furniture and home accent.

- The stores are large-format and stock stuff for the house coordinated furniture for the bedrooms and living rooms, and some home accessories as well, mostly sourced and imported from other companies. Nilkamal has tied up with Sleek, a

Mumbai-based modular kitchens company, to equip customers' kitchens.

- Offers a computerised service for customers to plan the look of their homes with merchandise bought there

- Nilkamal has tied up with ICICI Bank and HDFC bank to provide loans.

o Nilkamal has spent Rs 50 crore on the retail business and will invest Rs 75 crore more in the next three years. company aims to have 38 stores operating by 2010.It expects the business to contribute over Rs 350 crore by 2010

- Conveniently located it in malls with good branding and service.

- Aimed to charm the white collar class and the trying fragment of the general public 


\section{Macrothink \\ International Journal of Accounting and Financial Reporting \\ ISSN 2162-3082 \\ 2020, Vol. 10, No. 3}

\section{Recommendations \& Conclusion}

In order to be a dominant player in furniture industry, Nilkamal is suggested the following advertising strategies:

Nilkamal has not been very successful in promoting its brands in plastic furniture based on these lines. It can promote its brand based on these driving factors by:

1. Lightweight: Furniture which even your grand-mom can carry

a.People who redo their homes frequently

b. People who shift bases a lot based on career needs

2. Weatherproof: Furniture which even the rain/sun cant destroy

a. A furniture set - chairs, table lying in the terrace or in the open need not be covered in rain where as a wooden one would have to.

3. Termite-proof: Furniture which termites can't get a bite of

a. Your furniture is termite proof at no extra cost

b. This can be targeted at the rural market specially as termite problems are more prominent in rural areas

4. Available in a wide range of colours: Style your furniture to match with the colour of your walls

a. Women can choose the colour of their furniture to match with the colour on their walls

b. Wooden finished plastic furniture can be promoted

c. Colours won't fade

5. Economical: All these benefits at such a low price: who won't buy?

a. This would also run at a risk of Plastic Furniture being considered as an inferior good so advertise in a way to show that classy furniture is being offered at an economical price.

\section{References}

Bhatnagar, S. (2017). A Study of Retail Customer Services with Special Reference to Organized Retailing in India. Imperial Journal of Interdisciplinary Research, 3(2).

Flikkema, M., Castaldi, C., de Man, A. P., \& Seip, M. (2019). Trademarks' relatedness to product and service innovation: A branding strategy approach. Research Policy, 48(6), $1340-1353$.

Gummesson, E., Kuusela, H., \& Närvänen, E. (2014). Reinventing marketing strategy by recasting supplier/customer roles. Journal of Service Management, 25(2), 228-240. 


\section{MInstitute ${ }^{m}$ Macrothink}

International Journal of Accounting and Financial Reporting

ISSN 2162-3082

Iqbal, H. (2018). Modern Retailing in the Sub-continent and its Various Facets: Evidence from Literature. International Journal, 6(2).

Masuda, S. (2017). Indonesian wooden furniture value chain and impacts of EU policies.

Narain, R. (2017, February). Counteracting the barriers to adoption of mass customization practices in Indian SMEs: A case of furniture industry. In Advances in Mechanical, Industrial, Automation and Management Systems (AMIAMS), 2017 International Conference on (pp. 48-52). IEEE.

Pangemanan, S. A., \& Walukow, I. M. (2018, January). Marketing Strategy Analysis for Small and Medium Scale Business Enterprise (SMEs) for Home Industry Furniture in Leilem, the Regency of Minahasa. In Journal of Physics: Conference Series (Vol. 953, No. 1, p. 012033). IOP Publishing.

Petersen, M. A. (2017). Teuer furniture (A): Discounted cash flow valuation. Kellogg School of Management Cases, 1-23.

Schlegelmilch, B. B. (2016). The Future of Global Marketing Strategy. In Global Marketing Strategy (pp. 221-249). Springer, Cham.

Wang, Y., Yu, Z., \& Ye, B. (2016). Research on the Innovative Design of Building Block Type Modular Furniture. Furniture, 6, 012.

Wensley, R. (2016). The basics of marketing strategy. In The marketing book (pp. 75-107). Routledge.

\section{Copyright Disclaimer}

Copyright for this article is retained by the author(s), with first publication rights granted to the journal.

This is an open-access article distributed under the terms and conditions of the Creative Commons Attribution license (http://creativecommons.org/licenses/by/4.0/) 